Inventa: Jurnal Pendidikan Guru Sekolah Dasar

http://jurnal.unipasby.ac.id/index.php/jurnal_inventa

\title{
IMPLEMENTASI PANCASILA DALAM KEHIDUPAN DI MASA PANDEMI COVID-19
}

\author{
Jamilla Agustin Ummu Sholih ${ }^{1)}$ Dinie Anggraeni Dewi ${ }^{2)}$ \\ ${ }^{1)}$ Universitas Pendidikan Indonesia
}

Corresponding author E-mail: jamillaags27@upi.edu

\begin{abstract}
Abstrak
Kata Kunci:

Implementasi, Pancasila, Pandemi Covid-19

Penelitian ini bertujuan untuk memberikan gambaran tentang bagaimana pengimplementasian nilai-nilai pancasila pada kondisi saat ini yaitu covid-19. Metode penelitian menggunakan pendekatan kualitatif atau pendekatan secara dekripstif. Yang mana teori ataupun dasar pembahasannya diperoleh dari hasil studi kepustakaan dari berbagai sumber seperti jurnal, buku, dan artikel. Kemudian, diperoleh hasil bahwa saat ini tanpa masyarakat sadari bahwa pengimplementasian nilai-nilai pancasila di saat pandemi ini mulai meningkat. Adanya wabah ini membuat masyarakat lebih saling toleransi dan terbuka akan saling tolong menolong sesama. Kegiatan hal tersebut merupakan salah satu penerapan dari nilainilai pancasila. Maka, pancasila pada hakikatnya merupakan salah satu pandangan hidup bangsa dan sebagai suatu dasar negara dalam berkehidupan.
\end{abstract}

\begin{tabular}{ll}
\hline Keyword: & Abstract: \\
Implementation, & $\begin{array}{l}\text { This research aims to describe an overview of how the values of Pancasila are } \\
\text { implemented in the current conditions, namely Covid-19. The research method uses } \\
\text { Pancasila, Pandemic }\end{array}$ \\
a qualitative approach or a descriptive approach. Which theory or basis for \\
discussion is obtained from the results of literature studies from various sources \\
such as journals, books and articles. Then, the results showed that currently without \\
the public realizing that the implementation of Pancasila values at the time of this \\
pandemic began to increase. The existence of this epidemic makes the community \\
more tolerant and open to helping each other. This activity is one of the applications \\
of Pancasila values. So, Pancasila is essentially a view of the life of the nation and \\
as a basis for the state in living.
\end{tabular}

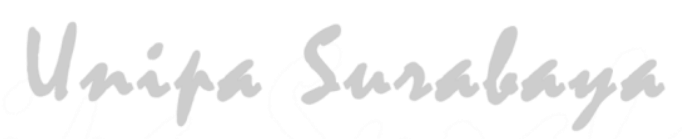




\section{Pendahuluan}

Dunia dihebohkan dengan satu pandemi yang membuat banyak kerugian, tak terkecuali negara Indonesia. Permasalahan yang timbul karena adanya satu wabah penyakit virus yaitu virus covid 19. Wabah ini pertama kali terdapat di Wuhan, Cina pada Desember 2019. Virus ini bernama coronavirus.

Coronavirus merupakan salah satu virus yang menyebabkan penyakit pada manusia dan hewan. Pada manusia biasanya menyebabkan penyakit infeksi saluran pernapasan. Selain itu juga, virus ini menyebabkan kematian yang banyak merenggut nyawa manusia (sumber: infeksimerging.kemkes).

Virus ini menyebar sangat cepat, akhirnya WHO menetapkan virus corona sebagai pandemi 11 Maret 2020. Status pandemi atau epidemi global menandakan bahwa penyebaran Covid-19 berlangsung cepat hingga hampir tak ada negara di dunia yang dapat memastikan diri terhindar dari virus corona. Beberapa negara juga menerapkan lockdown untuk mencegah penyebaran virus corona seperti negara Cina, Spanyol, Italia, dan Malaysia. Pemerintah negara tersebut memutuskan untuk lockdown dengan menutup semua akses fasilitas publik dan transportasi (Mona, 2020).
Akibat dari hal tersebut, Indonesia juga sempat memutuskan untuk lockdown hanya saja tidak semua akses di batasi. Dampak yang ditimbulkan dari pandemi ini juga bukan hanya hal yang biasa. Mulai dari perekonomian, politik, lalu juga pendidikan terkena dampak dari pandemi ini. Namun, setelah adanya wabah ini manusia menjadi sadar bahwa betapa pentingnya kesehatan bagi tubuh. Karena, adanya pandemi ini manusia menjadi saling peduli dan bekerja sama dalam menyelesaikan permasalahan ini. Selain itu juga, manusia menjadi lebih mendekatkan diri kepada Tuhan Yang Maha Esa yang telah memberikan cobaan ini.

Dilihat dari penjelasan diatas, di masa pandemi ini tumbuh rasa-rasa yang dahulu sempat pudar namun sekarang berkembang lagi. Nilai-nilai Pancasila yang sempat hilang dari diri warga negara Indonesia. Setelah adanya pandemi ini manusia menjadi lebih sadar bahwa pentingnya menerapkan nilai-nilai pancasila. Pancasila sebagai dasar falsafah negara dan dasar negara Indonesia sekaligus sebagai ideologi bangsa yang menjadikannya sebuah jati diri bangsa Indonesia.

Sejarah mencatat, Pancasila yang diinisasi pertama kali pada tanggal 1 Juni 1945 adalah source of energy, yaitu 
sebagai kekuatan dan sekaligus sebagai guidelines dalam memperoleh kemerdekaan, menjadi media pemersatu dalam menciptakan kerukunan berbangsa, serta sebagai pandangan hidup atau philosophie grondslag sehari-hari bagi bangsa Indonesia (Brata dan Wartha, 2017).

Pancasila ini akan selalu melekat dalam diri bangsa Indonesia. Mempelajari Pancasila akan menyadarkan kita sebagai bangsa Indonesia yang memiliki jati diri dan harus diwujudkan dalam pergaulan hidup sehari-hari untuk menunjukan sebuah identitas bangsa (Widiyanti,2020). Jika dilihat dari situasi saat ini pentingnya kita untuk bisa mengimplementasikan Pancasila sebagai suatu dasar pandangan hidup dalam menyelesaikan permasalahan ini.

Pancasila ini juga merupakan suatu bekal untuk kita dalam berkehidupan berbangsa dan bernegara dengan menerapkan nilai-nilai yang ada pada Pancasila. Bagaimanapun situasi dan kondisi negara saat ini kita harus tetap menjadikan Pancasila sebagai sebuah pandangan hidup dan dasar negara agar sesuai dengan tujuan dan cita-cita bangsa Indonesia.

Jika dilihat saat ini, adanya sebuah peningkatan dalam menerapkan nilai-nilai
Pancasila. Pandemi ini menyadarkan banyak orang dan juga implementasi pada Pancasila diterapkan. Seperti pada sila pertama dimana saat ini orang-orang menjadi lebih dekat pada tuhannya dalam menghadapi pandemi ini. Lalu juga saling toleransi dan sila-sila lainnya juga diterapkan pada kehidupan masyarakat.

Berdasarkan uraian diatas pentingnya penerapan pada tiap sila-sila dalam Pancasila. Sebagai makhluk yang memiliki akal dan berpikir diperlukannya Pancasila sebagai pedoman hidup bangsa dan bernegara apalagi dalam menyelesaikan permasalahan saat ini.

\section{Metode}

Penelitian ini menggunakan pendekatan kualitatif dengan metode dekriptif. Metodologi merupakan suatu formula dalam penerapan penelitian dimana dalam melakukan penelitian tersebut terdapat langkah-langkah dan juga hasil penelitian (Ariani,2014). Metode penelitian kualitatif merupakan suatu prosedur pengambilan data yang menghasilkan data deskriptif berupa katakata tertulis dari fenomena dan perilaku tertentu (Sihombing, 2021). Sumber teori yang diambil dari hasil studi kepustakaan dari berbagai referensi seperti buku, jurnal, 
artikel ataupun media lainnya yang berhubungan dengan penelitian ini.

\section{Hasil dan Pembahasan}

\section{Pengertian Pancasila}

Menurut Prof. Dr. Soepomo dan Prof. Dr. Hamid At-tamimi Pancasila merupakan cita hukum bagi bangsa Indonesia yang harus dilaksanakan secara konsisten dalam kehidupan (Soeprapto, 2005). Pendidikan Pancasila merupakan salah satu cara untuk menanamkan pribadi yang bermoral dan berwawasan luas dalam kehidupan berbangsa dan bernegara (Kristiono,2017). Menurut Soekarno Pancasila bukan hasil dari pemikirannya namun berdasarkan bangsa Indonesia yang sudah ada dalam diri bangsa dan terdapat lima prinsip yang diajukan yaitu nasionalisme, internasionalisme, mufakat, kesejahteraan sosial, ketuhanan yang maha esa (Hasanah, 2020). Pancasila sebagai dasar dan ideologi negara merupakan hasil kesepakatan bapak pendiri bangsa ketika negara Indonesia didirikan, dan hingga saat ini di era globalisasi (Lestari,2019).

\section{Pancasila Sebagai Ideologi Bangsa}

Kata "idea" berasal dari kata bahasa Yunani "eidos" yang artinya "bentuk". Selain itu terdapat kata lain yaitu "idein" yang berarti "melihat". Secara harfiah ideologi adalah ilmu pengetahuan tentang ide-ide, atau ajaran tentang pengertian dasar atau cita-cita yang bersifat tetap dan harus dicapai sebagai dasar, pandangan, atau paham (Kaelan, 2016).

Menurut Notonegoro ideologi negara sebagai cita-cita negara, atau cita-cita yang menjadi basis bagi suatu teori atau sistem ketatanegaraan untuk seluruh rakyat dan bangsa yang bersangkutan yang pada hakekatnya merupakan asas kerohanian yang antara lain memiliki ciri sebagai berikut (Muslimin,2016):

a. Mempunyai derajat yang tertinggi sebagai nilai hidup kebangsaan dan kenegaraan.

b. Untuk mewujudkan suatu asas kerohanian, pandangan hidup, pegangan hidup yang dipelihara dikembangkan, diamalkan, dilestarikan kepada generasi berikutnya, diperjuangkan dan dipertahankan dengan kesediaan berkorban.

Menurut pandangan Soekarno Pancasila ini digali dari bumi pertiwi yang artinya berasal dari negara Indonesia sendiri. Bahwa Pancasila berisi nilai-nilai moral dan budaya bangsa yang sudah ada sejak bangsa Indonesia berdiri. Nilai-nilai tersebut tidak secara sengaja digunakan 
begitu saja, namun melalui sebuah proses panjang yang terbuka dan bersifat demokratis dari sebuah kesepakatan bersama.

Pancasila juga sebagai ideologi terbuka yaitu yang dimiliki seluruh rakyat sehingga masyarakat dapat menemukan dirinya, kepribadiannya didalam ideologi tersebut. Ideologi ini berisi tentang nilai-nilai dasar. Ideologi ini juga bersifat aktual, dinamis, antisipatif, dan senantiasa mampu menyesuaikan dengan perkembangan zaman. Sebagai ideologi terbuka maka Pancasila memiliki dimensi sebagai berikut:

a. Dimensi idealis, yaitu nilai-nilai dasar yang terkandung dalam Pancasila bersifat sistematis dan rasional yaitu hakikat nilai-nilai yang terkandung dalam lima sila yaitu ketuhanan, kemanusiaan, persatuan, kerakyatan, dan keadilan.

b. Dimensi normatif, nilai-nilai yang terkandung dalam Pancasila perlu dijabarkan dalam suatu sistem norma yaitu yang terdapat pada Pembukaan UUD 1945 yang memiliki keduudkan tertinggu dalam tertib hukum Indonesia

c. Dimensi realistis, ideologi yang harus mampu mencerminkan realitas yang hidup dan berkembang dalam masyarakat oleh karena itu Pancasila selain memiliki dimensi nilai-nilai ideal normatif, maka pancasila harus dijabarkan dalam kehidupan nyata sehari-hari.

\section{Pancasila Sebagai Dasar Negara}

Pancasila sebagai dasar negara pada hakikatnya adalah sumber dari segala sumber hukum. Hal ini mengandung konsekuensi yuridus yaitu bahwa seluruh aturan perundang-undangan Republik Indonesia harus sejiwa dan sejalan dengan Pancasila. Pokok-pokok pikiran yang terdapat dalam Pembukaan UUD NRI 1945 yang didalamnya terdapat dasar negara Pancasila yang sudah tentu menjadi dasar bagi penyelenggaraan negara.

\section{Nilai-Nilai yang Terkandung dalam} Pancasila

Pandangan hidup bangsa yang berisi nilai-nilai yang sudah ada sebelum bangsa Indonesia terbentuk ialah Pancasila sebagai pandangan hidup bangsa. Secara kultural dasar-dasar pemikiran tentang Pancasila dan nilai-nilai Pancasila berakar pada nilainilai kebudayaan dan nilai-nilai religius yang dimiliki oleh bangsa Indonesia sendiri sebelum mendirikan negara (Muslimin,2016).

Sebagai suatu dasar filsafat negara maka sila-sila pancasila merupakan suatu 
sistem nilai dan pada hakikatnya adalah suatu kesatuan. Pancasila memiliki serangkaian nilai, yaitu ketuhanan, kemanusiaan, persatuan, kerakyatan, dan keadilan. Nilai-nilai Pancasila juga sebagai suatu pandangan hidup bangsa Indonesia. Pancasila juga merupakan nilai-nilai yang sesuai dengan hati nurani bangsa Indonesia, karena bersumber pada kepribadian bangsa. Nilai-nilai Pancasila ini menjadi landasan dasar, serta motivasi atas segala perbuatan baik dalam kehidupan sehari-hari dan dalam kenegaraan (Asmaroini, 2016).

Adapun nilai-nilai yang terkandung dalam setiap sila Pancasila sebagai berikut:

a. Ketuhanan Yang Maha Esa

Dalam sila pertama ini terkandung bahwa adanya prinsip asasi kepercayaan dan ketaqwaan kepada tuhan yang maha esa, kebebasan beragama dan berkepercayaan pada Tuhan Yang Maha Esa sebagai hak yang paling asasi bagi manusia, toleranis diantara umat bergaama dan kepercayaan, kecintaan pada semua makhluk ciptaan tuhan

b. Kemanusiaan Yang Adil dan Beradab Sila kedua ini terkandung nilai-nilai bahwa negara harus menjunjung tinggi harkat dan martabat manusia sebagai makhluk yang beradab. Selai itu juga mengandung sikap moral dan tingkah laku manusia seperti kejujuran, kesamaderajatan manusia, keadilan dan keadaban

c. Persatuan Indonesia Manusia sebagai makhluk individu dan sosial sehingga manusia memiliki perbedaan individu, suku, ras, kelompok, golongan, maupun agama. Akibatnya disuatu negara tersebut harus menjadi satu kesatuan meskipun berbeda-beda dan cinta terhadap tanah air.

d. Kerakyatan Yang Dipimpin Oleh Hikmat Kebijaksanaan dalam Permusyawaratan Perwakilan

Dalam sila keempat terdapat nilai demokrasi yang harus dilaksanakan dalam kehidupan negara. Selain itu juga terdapat prinsip asasi kerakyatan, dan musyawarah mufakat (Suyahmo,2015).

e. Keadilan Sosial Bagi Seluruh Rakyat Indonesia

Dalam sila kelima ini terkandung bahwa seluruh warga negara Indonesia harus merasakan keadilan, keadilan sosial, kesejahteraan lahir dan batin, lalu juga kekeluargaan dan kegotongroyongan. 
Jika dilihat dari nilai-nilai yang terkandung dalam tiap sila Pancasila memiliki makna nya masing-masing. Sehingga menjadi bukti bahwa Pancasila ini penting sebagai pandangan atau arah hidup bangsa.

\section{Implementasi Nilai-Nilai Pancasila di} Masa Pandemi

Penerapan merupakan sebuah tindakan yang dilakukan baik secara individu maupun kelompok dengan maksud untuk mencapai tujuan yang telah dirumuskan (Harahap, 2019). Pandemi Covid-19 adalah krisis kesehatan yang pertama dan terutama di dunia yang menyebabkan banyak kerugian/besar dirasakan oleh tiap negara (Purwanto,2020).

Di masa pandemi ini, penanaman nilainilai pancasila meningkat. Dimana ini merupakan sebuah wabah yang sangat menghebohkan di dunia. Seluruh masyarakat terutama Indonesia terkena dampak dari pandemi ini. Namun, dengan adanya pandemi ini kita bisa mengimplementasikan nilai-nilai pancasila.

Pandemi ini merupakan sebuah masalah yang memerlukan respon yang cepat dari lembaga informasi yang sejatinya memiliki tugas utama memberikan informasi yang berguna bagi peningkatan pengetahuan (Widianti,2020).
Hal ini juga bisa terjadi karena adanya globalisasi yang semakin maju. Pastinya bangsa dan negara Indonesia ingin berdiri kokoh kuat, tidak mudah terkecoh oleh kerasnya masalah kehidupan berbangsa dan bernegara. Bentuk implementasi dari nilai-nilai Pancasila di masa pandemi ini sebagai berikut:

a. Sila Kesatu "Ketuhanan Yang Maha Esa"

Adanya pandemi ini, masyarakat menjadi lebih mendekatkan diri kepada Tuhan Yang Maha Esa, dan manusia juga disadarkan adanya sebuah relasi antara Tuhan Yang Maha Esa, manusia, dan alam semesta. Wabah covid-19 ini bagian dari ujian dalam kehidupan yang harus bisa menyadarkan manusia bahwa tidak ada yang memiliki kuasa selain Tuhan Yang Maha Esa.

Selain itu juga, adanya sikap saling toleransi antar umat beragama agar dapat melaksanakan keyakinan beribadahnya masingmasing sesuai dengan pedoman protokol kesehatan yang disampaikan oleh pemerintah (Achmadi,2020). Kita sebagai bangsa yang beragama tentunya dalam menyikapi pandemi corona 
ini perlu dilandasi kecerdasan spiritual dan kecerdasan ekologis.

b. Sila Kedua "Kemanusiaan Yang Adil dan Beradab"

Pada sila kedua ini menjelaskan bahwa setiap manusia merupakan makhluk yang beradab dan diperlakukan sesuai harkat dan martabatnya. Lalu juga memiliki derajat, hak dan kewajiban yang sama. Pada dasarnya manusia membangun budaya, nilai-nilai dan norma yang dijadikan sebuah landasan dalam bersikap dan bertingkah laku di masyarakat. Penerapan pada sila ke dua ini pada masa pandemi adalah manusia saling bahu-membahu untuk melakukan pencegahan penyebaran Covid-19 maupun menghilangkan ego masing-masing individu. Pegamalan lainnya adalah dengan menjaga kesehatan diri pada tiap masing-masing individu seperti memakai masker, mencuci tangan atau menggunakan handsainitiser agar ketika kita sakit tidak menularkan pada yang lain atau tertular oleh orang lain.

Selain itu juga pada asas kemanusiaan, adanya sebuah perhatian lebih antara manusia dengan manusia lainnya. Dalam situasi pandemi ini aspek kemanusian pada sisi kesehatan, ekonomi, sosial, agama, hukum, budaya dan lain sebagainya sangatlah diperlukan menjadi perhatian dan menjadi dasar bagi penyelenggaraan negara dan relasi sesama manusia. Dan tidak lupa juga setiap warga negara supaya selalu patuh dan taat pada protokol kesehatan dan kebijakan yang telah dikeluarkan oleh pemerintah dalam menanggulangi pandemi ini.

c. Sila Ketiga "Persatuan Indonesia"

Pada sila ini memberikan karakteristik yang holistis atas paham kebangsaan Indonesia dan didalamnya terkandung makna nasionalisme. Istilah nasionalisme memiliki dua pengertian yaitu paham untuk mencintai bangsa dan negara sendiri dan kesadaran keanggotaan dalam suatu bangsa yang secara potensial atau aktual bersama mencapai, mempertahankan dan mengabadikan identitas, integritas, kemakmuran dan kekuatan bangsa (Lestari,2019).

Dalam konteks situasi pandemi dibutuhkannya rasa nasionalisme, 
kekeluargaan, kebersamaan dan gotong royong ini. Saling tolong menolong sesama manusia dalam menghadapi dan mengatasi pandemi ini dnegan memberukan sebuah bantuan materil maupun non materi dan tidak lupa juga doadoa untuk saudara kita yang lain. Lalu juga, melepaskan ego kita untuk bisa memiliki sifat empati dan menghormati kepada petugas yang menangani kasus covid-19 ini terutama pada tim medis, relawan, dan petugas lainnya. Saat ini juga dengan adanya pandemi ini menggerakan rasa empati kemanusiaan yang melahirkan persatuan dan gotong royong untuk menyelesaikan masalah. Kebersamaan dan gotong royong ini akan mempercepat penanganan pandemi. Saling membantu tanpa melihat ras, suku, dan agama adalah esensi sila ketiga Pancasila.

d. Sila Keempat "Kerakyatan Yang Dipimpin Oleh Hikmat Kebijaksanaan Dalam Permusyawaratan Perwakilan"

Pada sila ini memebrikan makna adanya sifat kebijaksanaan dan tanggung jawab terhadap Tuhan Yang Maha Esa maupun terhadap sesama manusia. Kebijaksanaan pemimpin dibutuhkan untuk menghasilkan kebijakan negara yang benar-benar berorientasi pada kepentingan rakyat dalam menangani pandemi dan dampaknya pada keberlangsungan penghidupan (Widianti,2020). Penerapan pada saat pandemi ini adalah adanya kerjasama antara tokoh-tokoh masyarakat tentang pentingnya menjalani himbauan pemerintah agar tidak beraktivitas diluar rumah. Koordinasi ini dilakukan dengan cara bermusyawarah bersama dengan para tokoh.

Demokrasi juga menjadi makna yang kental untuk sila keempat ini seperti dalam upaya penanganan pandemi corona ini dimana tidak hanya pemerintah saja yang harus berperan tetapi masyarakat juga menjadi unsur penting. Setiap aturan yang ditetapkan oleh pemerintah adalah hasil musyawarah bersama. Seperti social distancing, WFH, diliburkannya sekolah, dan beberapa waktu untuk Lockdown itu semua diatur dengan cara bermusyawarah. 
e. Sila Kelima "Keadilan Sosial Bagi Seluruh Rakyat Indonesia

Sila kelima ini yaitu keadilan yang menyangkut bagi seluruh rakyat Indonesia. Keadilan yang dimaksud adalah pemerintah tidak membeda-bedakan ras, agama, pekerjaan, budaya dan hal adil juga terhadap seluruh warga negara seperti sifat menolong dan menghargai sesama melakukan pekerjaan yang membantu untuk kepentingan bersama. Selain lainnya pada rakyatnya. Bersikap

Pengimplementasian

nilai-nilai Pancasila ini juga diperlukan dalam menghadapi pandemi ini. Meningkatnya sebuah penerapan nilai-nilai Pancasila hal yang positif bagi bangsa Indonesia. Menyadarkan bahwa Pancasila ini memang betul sebagai dasar negara dan pandangan hidup bangsa. Dimana permasalahan yang ada jika berpatokan pada nilai-nilai Pancasila dan menerapkannya akan menjadi lebih mudah mengatasinya dan warga negara juga akan merasa adil

\section{Daftar Pustaka}

Achmadi, R, Z. (2020). Implementasi

\section{Kesimpulan}

Pancasila merupakan salah satu pedoman bagi hidup bangsa yang menjadikan ideologi dan dasar negara. Nilai-nilai Pancasila yang tertuang dalam sila-sila Pancasila tentunya perlu tertanam disetiap hati masyarakat Indonesia. Nilainilai tersebut menjadi sebuah pedoman dan patokan dalam bernegara dan bermasyarakat bagi seluruh rakyat Indonesia. Selain itu juga, dimasa pandemi ini Pancasila menyadarkan kita bahwa pentingnya menanamkan sikap dan perilaku yang sesuai sila-sila Pancasila. Menyadarkan kita tentang spritual, menumbuhkan rasa empati, tenggang rasa dan cinta bagi sesama manusia.
Nilai-Nilai Pancasila Pada Masa Pandemi Covid 19 (Studi Kasus pada Angkatan Muda Partai Golkar di Kecamatan Gondangrejo Kabupaten Karanganyar). Skripsi FKIP Universitas Muhammadiyah Surakarta : tidak diterbitkan. [PDF].

Ariani, A.P. (2014). Aplikasi Metodologi Penelitian Kebidanan dan Kesehatan. Yogyakarta: Nuha Medika. [EBOOK].

Asmaroini, A,P. (2016). Implementasi Nilai-Nilai Pancasila Bagi Siswa di Era Globalisasi. Jurnal Pancasila dan Kewarganegaraan, Vol 4(2). [PDF]. 
Brata dan Wartha. (2017). Lahirnya Pancasila Sebagai Pemersatu Bangsa Indonesia. Jurnal Santiaji Pendidikan,Vol 7(1), hlm 120-122. $[\mathrm{PDF}]$.

Harahap,F,H. (2019). Penerapan Algoritma

Turbo Booyermoore Dalam Pencarian Rekam Medis Pasien Pada RS. Bunda Thamrin. Jurnal Pelita Informatika,Vol 7(3), hlm 319-320. [PDF].

Hasanah. (2020). Pemikiran Soekarno Dalam Perumusan Pancasila. Jurnal Candi, Vol 20(2), hlmn 5152. [PDF].

Informasi Tentang Virus Corona. Tersedia: https://infeksiemerging.kemkes.go.i d/ . [Online].

Kaelan. (2016). Pendidikan Pancasila. Yogyakarta Paradigma. [EBOOK].

Kristiono,Natal. (2017). Penguatan Ideologi Pancasila di Kalangan Mahasiswa Universitas Negeri Semarang. Harmony, Vol 2(2). [PDF].

Lestari, Janah, dan Wardani. (2019). Menumbuhkan Kesadaran Nasionalisme Generasi Muda di Era Globalisasi Melalui Penerapan Nilai-Nilai Pancasila. Adil Indonesia Jurnal, Vol 1(1).
Universitas Negeri Semarang. [PDF].

Mona,N. (2020). Konsep Isolasi Dalam Jaringan Sosial Untuk Meminimalisasi Efek Contagious. Jurnal Sosial Humaniora Terapa, Vol 2(2),hlm 117-118. [PDF].

Muslimin,Husein. (2016). Tantangan Terhadap Pancasila Sebagai Ideologi dan Dasar Negara Pasca Reformasi. Jurnal Cakrawala Hukum, Vol 7(1). Universitas Merdeka Malang. [PDF].

Purwanto,dkk. (2020). Studi Eksploratif Dampak Pandemi Covid-19 Terhadap Proses Pembelajaran Online di Sekolah Dasar. Journal of Education Psychology and Counseling, Vol 2(1)hlm 1-2. [PDF].

Sihombing, R,A. (2021). Peranan Penting Pancasila dan Pendidikan Kewarganegaraan Sebagai Pendidikan Karakter di Masa Pandemi Covid-19. Jurnal Pendidikan Kewarganegaraan Undiksha, Vol 9(1), hlm 52-53. [PDF].

Soeprapto. (2005). Implementasi Pancasila Dalam Kehidupan Bermasyarakat, Berbangsa, dan Bernegara. Jurnal 
Ketahanan Nasional, Vol 10(2).

[PDF].

Suyahmo. (2015). Model Implementasi

Sila Ke 4 "Kerakyatan Yang

Dipimpin Oleh Hikmat

Kebijaksanaan

Dalam

Permusyawaratan/ Perwakilan”

Sebagai Lokus Pendidikan

Demokrasi Di SMP Kota

Semarang. Jurnal Penelitian

Pendidikan, Vol 32(1). Universitas

Negeri Semarang. [PDF].

Widiyanti, R,A. (2020). Implementasi

Nilai-Nilai Dasar Pancasila Dalam

dan Pasca Covid 19 Demi

Menyongsong Era Adaptasi

Kebiasaan Baru (AKB). Jurnal

Pendidikan Sosial Keberagaman,

Vol 7(2), 138-140. [PDF]. 